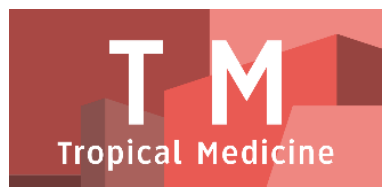

PAPER - OPEN ACCESS

\title{
Kajian Ketoksikan Ekstrak Etanol Kulit Buah Markisah Ungu (Passiflora Edulis Sims.) Terhadap Hati Mencit
}

Author : Herawaty Ginting

DOI $\quad: 10.32734 /$ tm.v1i1.85

Paper Page : $257-263$

Volume 1 Issue 1 - 2018 TALENTA Conference Series: Tropical Medicine (TM)

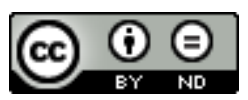

This work is licensed under a Creative Commons Attribution-NoDerivatives 4.0 International License.

Published under licence by TALENTA Publisher, Universitas Sumatera Utara
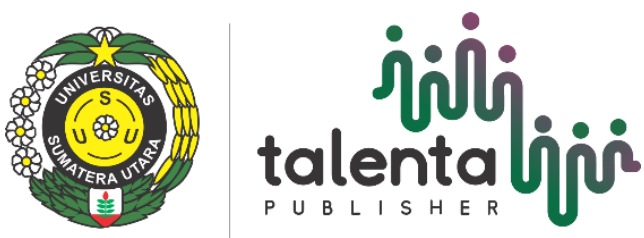


\title{
Kajian Ketoksikan Ekstrak Etanol Kulit Buah Markisah Ungu (Passiflora Edulis Sims.) Terhadap Hati Mencit
}

\author{
Herawaty Ginting ${ }^{\mathrm{a}, *}$, Aminah Dalimunthe ${ }^{\mathrm{b}}$, Edo Kusda Pratama ${ }^{\mathrm{a}}$ \\ ${ }^{a}$ Departmen Biologi Fakultas Farmasi, Universitas Sumatera Utara, Medan, 20158, Indonesia \\ ${ }^{b}$ Departmen Farmakologi Fakultas Farmasi, Universitas Sumatera Utara, Medan 20155, Indonesia \\ hera_ginting@yahoo.co.id
}

\begin{abstract}
Abstrak
Latar belakang: Buah markisah ungu (Passiflora edulis Sims.) banyak dikonsumsi masyarakat sebagai minuman yang segar. Kulit buah markisah berkhasiat sebagai antihipertensi, antimikroba dan antiinflamasi Tujuan penelitian: untuk mengetahui dosis toksik (LD50), sehingga aman untuk digunakan sebagai obat. Metode penelitian: menggunakan mencit sebanyak 25 ekor yang dibagi menjadi 5 kelompok, yaitu kelompok kontrol (Na-CMC 0,5\%), kelompok perlakuan diberi ekstrak etanol kulit buah markisa ungu (EEKBMU) dengan variasi dosis 500, 1000, 2000 dan $5000 \mathrm{mg} / \mathrm{kg}$ bb). Pada akhir pengujian dilakukan pengamatan terhadap gejala toksik, berat badan, kematian hewan, serta pemeriksaan makropatologi dan gambaran histopatologi hati mencit. Hasil penelitian: pemberian EEKBMU (Passiflora edulis Sims.) untuk semua kelompok tidak ada hewan yang mati. Kelompok kontrol, dosis $500 \mathrm{mg} / \mathrm{kg} \mathrm{bb}, 1000 \mathrm{mg} / \mathrm{kg}$ bb tidak menunjukkan gejala toksik tetapi pada dosis $2000 \mathrm{mg} / \mathrm{kg}$ bb dan $5000 \mathrm{mg} / \mathrm{kg}$ bb menunjukkan gejala toksik. Hasil pemeriksaan histopatologi organ hati mencit menunjukkan bahwa pemberian EEKBMU dosis $2000 \mathrm{mg} / \mathrm{kg}$ bb terjadi nekrosis hemorrhagia pada vena sentral, sedang dosis $5000 \mathrm{mg} / \mathrm{kg}$ bb terjadi nekrosis dan hemorrhagia yang meluas. Kesimpulan: EEKBMU dosis $2000 \mathrm{mg} / \mathrm{kg}$ bb dan $5000 \mathrm{mg} / \mathrm{kg}$ bb sangat toksik dan LD50 tidak dapat ditentukan.
\end{abstract}

Kata Kunci: Passiflora Edulis Sims; Kajian Ketoksikan; Kulit Buah Markisa Ungu

\section{Pendahuluan}

Penggunaan bahan alami untuk kesehatan di Indonesia telah berkembang sangat pesat. Manusia mulai menyadari akan pentingnya penggunaan bahan-bahan alami untuk proses pengobatan, berbagai obatobatan alternative kini dipilih sebagai pengobatan yang lebih aman daripada pengobatan dengan obatobat berbahan kimia (Purwaningsih, dkk., 2015).

Salah satu buah yang banyak dikonsumsi masyarakat sebagai minuman yang segar adalah buah markisah ungu (Passiflora edulis Sims.) termasuk suku Passifloraceae. Ternyata penelitian terhadap kulit buah markisah ungu telah banyak dilakukan seperti: ekstrak metanol kulit buah markisah berkhasiat sebagai antihipertensi [3]. Ekstrak air daun markisah mempunyai aktivitas antiinflamasi [13].

Bahan obat alami diyakini dapat memulihkan kesehatan manusia dari berbagai penyakit dan tanpa memiliki effek samping yang berarti. Senyawa kimia yang terdapat bahan obat alami dapat saja tidak memiliki efek toksik bagi tumbuhan tersebut, namun belum tentu pada manusia [11]. Penggunaan bahan alami yang terus-menerus dapat menyebabkan hal yang tidak diinginkan terhadap organ tubuh, oleh karena itu keamanan merupakan hal yang paling penting untuk diketahui [13]. 
Uji ketoksikan (toksisitas) merupakan salah satu uji yang digunakan untuk mengetahui keamanan suatu obat yang akan dijadikan produk. Toksisitas akut dilakukan untuk menentukan nilai toksisitas akut yang memberikan gambaran besarnya daya racun bahan alami [13].

Berdasarkan uraian diatas, maka dilakukan uji toksisitas akut terhadap ekstrak etanol kulit buah markisa ungu dengan menggunakan hewan percobaan mencit. Penelitian ini meliputi pengamatan gejala toksik, berat badan, konsumsi makanan dan minuman, kematian hewan, berat organ relatif, serta pemeriksaan makropatologi dan histopatologi organ hati mencit.

\section{Metode Penelitian}

- Alat Alat

Seperangkat alat bedah, waterbath, neraca hewan, spuit mikroskop cahaya. mikrotom, dan incubator.

- Bahan-bahan

Bahan tumbuhan yang digunakan dalam penelitian ini adalah kulit buah markisa ungu (Passiflora edulis Sims). Bahan kimia yang digunakan adalah aquades, Na-CMC (Natrium Carboxy Methyl Cellulose), formaldehyd 37\%, larutan hematoxylin, larutan eosin, etanol 70\%, etanol 80\%, etanol 96\%, etanol absolut, xylol, paraffin cair, cairan perekat (DPX).

- Hewan Penelitian

Mencit (MusMusculus) jantan yang sehat sebanyak 25 ekor dengan bobot 20-30 g. Mencit diaklimatisasi terlebih dahulu selama 7-14 hari.

- Skrining fito kimia simplisia

Skrining fitokimia simplisia kulit buah markisah ungu meliputi pemeriksaan senyawa golongan alkaloid, glikosida, steroid/triterpenoida, flavonoid, saponin, tanin dan antrakuinon.

- Pembuatan suspensi ekstrak etanol kulit buah markisa ungu (EEKBMU)

Dalam pengujian digunakan 4 variasi dosis yakni dosis $500 \mathrm{mg} / \mathrm{kg} \mathrm{bb}, 1000 \mathrm{mg} / \mathrm{kg} \mathrm{bb}, 2000 \mathrm{mg} / \mathrm{kg}$ bb dan 5000 $\mathrm{mg} / \mathrm{kg}$ bb. Ditimbang EEKBMU sebanyak $500 \mathrm{mg}, 1000 \mathrm{mg}, 2000 \mathrm{mg}, 5000 \mathrm{mg}$. Masingmasing dimasukkan kedalam lumpang dan ditambahkan suspensi Na-CMC $0,5 \% \mathrm{~b} / \mathrm{v}$ sedikit demi sedikit sambil digerus sampai homogen hingga $10 \mathrm{ml}$.

- Penyiapan dan pengelompokan hewan uji

Mencit dibagi ke dalam 5 kelompok, tiap kelompok terdiri dari 5 ekor mencit. Kelompok 1 sebagai kontrol, kelompok 2-5 sebagai kelompok perlakuan. Pembagian kelompok sebagai berikut :

Kelompok $1(\mathrm{~K})$ : Kontrol, diberi larutan suspensi Na-CMC 0,5\% b/v

Kelompok 2 (P1) : Perlakuan, diberikan EEKBMU dengan dosis $500 \mathrm{mg} / \mathrm{kg}$ bb

Kelompok 3 (P2) : Perlakuan, diberikan EEKBMU dengan dosis $1000 \mathrm{mg} / \mathrm{kg}$ bb

Kelompok 4 (P3) : Perlakuan, diberikan EEKBMU dengan dosis $2000 \mathrm{mg} / \mathrm{kg}$ bb

Kelompok 5 (P4) : Perlakuan, diberikan EEKBMU dengan dosis $5000 \mathrm{mg} / \mathrm{kg}$ bb

Waktu pengamatan adalah 5 menit, 10 menit, 15 menit, 30 menit, 60 menit, 120 menit, 180 menit dan 240 menit. Total waktu pengamatan 4 jam dan selama 14 hari. Pada perlakuan untuk mengamati efek toksik yang timbul dilakukan pengujian yang meliputi uji panggung, uji katalepsi, uji urinasi, uji defekasi dan uji salvasi, berat badan dan kematian dan histopatologi hati. Pengujian diulangi kembali pada mencit yang lain dalam kelompok yang sama, dilanjutkan dengan kelompok yang lain. Mencit diamati dan ditentukan LD50nya untuk menentukan tingkat toksisitas dengan melihat jumlah mencit yang mati.

- Penimbangan organ

Selesai pengamatan maka mencit dibedah, organ hati dikeringkan terlebih dahulu dengan kertas penyerap, kemudian segera ditimbang, sedangkan yang dianalisis adalah bobot relatif (indeks organ), yaitu bobot organ absolut dibagi bobot badan. 
- Pemeriksaan histopatologi

Organ yang diperiksa secara histopatologi adalah hati. Organ yang sudah dipisahkan dicuci dengan larutan fisiologis $0,9 \%$, kemudian dimasukkan dalam larutan dapar formalin $10 \%$ dan dibuat preparat histopatologi dengan pewarnaan hematoksilin \& eosin kemudian diperiksa di bawah mikroskop.

\section{Hasil dan Pembahasan}

\subsection{Hasil Skrining Fito Kimia}

Kandungan karoten minyak kelapa sawit cukup besar, namun diperlukan beberapa proses untuk memurnikan minyak tersebut bahkan mendapatkan kandungan karoten murni. Hasil analisis total karotenoid minyak sawit merah dan konsentrat karotenoid dapat dilihat pada Tabel 1.

Table. 1. Hasil Skrining Fito Kimia Simplisia

\begin{tabular}{lll}
\hline No & Pemeriksaan & Hasil \\
\hline 1 & Alkaloida & - \\
2 & Glikosida & + \\
3 & Steroida / Triterpenoida & + \\
4 & Flavonoida & + \\
5 & Tanin & - \\
6 & Saponin & + \\
7 & Antrakuinon & - \\
\hline Keterangan : $(+)=$ Memberikan reaksi & $(-)=$ Tidak memberikan reaksi \\
\hline
\end{tabular}

\subsection{Hasil Pengamatan Gejala Toksik}

Pengamatan terhadap pengujian efek toksik dilakukan pada setiap kelompok, efek toksik yang terjadi diamati dibandingkan dengan kontrol. Waktu pengamatan adalah 5 menit, 10 menit, 15 menit, 30 menit, 60 menit, 120 menit, 180 menit dan 240 menit. Total waktu pengamatan 4 jam. Pengamatan efek toksik meliputi uji panggung, uji urinasi, uji defekasi dan uji salivasi, berat badan, kematian mencit dan histopatologi.

Pemberian EEKBMU pada dosis 2000 dan $5000 \mathrm{mg} / \mathrm{kg}$ bb pada uji panggung ditemukan gejala toksik berupa penurunan aktivitas motorik mencit ditandai dengan abduksi, kaki terbuka karena adanya depresi SSP, ataksia (sempoyongan) dan reaksi refleks yaitu ketidakmampuan mencit membalikkan dirinya apabila diletakkan dengan punggung yang terbalik [7]

Pengamatan pada uji urinasi mencit setelah pemberian EEKBMU pada kelompok dosis 1000, 2000 dan 5000 $\mathrm{mg} / \mathrm{kg}$ bb pengeluaran urin mencit sudah sangat berlebihan. Pengeluaran urin yang berlebihan menunjukkan adanya sifat muskarinik [7].

Pada uji defekasi mencit setelah pemberian EEKBMU pada kelompok dosis 2000 dan $5000 \mathrm{mg} / \mathrm{kg}$ bb pengeluaran feses pada mencit sudah sangat berlebihan, mencit mengalami diare. Diare menunjukkan adanya adanya tanda-tanda muskarinik dan merupakan salah satu gejala toksik [7][9]. Semakin tinggi dosis maka semakin banyak kandungan zat aktif yang terdapat pada suspensi ekstrak, sebagaimana diketahui bahwa dosis merupakan hal utama yang menentukan apakah suatu zat kimia bersifat racun [8] hal ini jelas terlihat pemberian dosis 2000 dan $5000 \mathrm{mg} / \mathrm{kg}$ bb telah menunjukkan gejala toksik, tetapi golongan senyawa apa yang bertanggung jawab atas ketoksikan tersebut belum diketahui (tabel1) perubahan yang terjadi pada organ disebabkan adanya kandungan kimia pada ekstrak tersebut [7]. Pada uji salivasi yaitu tidak adanya pengeluaran saliva pada mencit pada semua kelompok, menunjukkan bahwa mencit masih dalam keadaan normal. Evaluasi toksisitas akut tidak hanya 
mengenai LD50 tetapi juga terhadap kelainan tingkah laku, stimulasi dan aktivitas motorik hewan uji untuk mendapatkan gambaran kematian [9]. Berdasarkan hasil pengamatan gejala toksik diatas terlihat bahwa mencit setelah pemberian EEKBMU menunjukkan adanya hubungan antara dosis dan efek toksik, semakin besar dosis yang diberikan maka semakin besar pula efek toksik yang timbul [5].

\subsection{Hasil Pengamatan Berat Badan}

Hasil uji statistik menunjukkan bahwa tidak terdapat perbedaan yang signifikan antara kelompok kontrol dan perlakuan (dosis 500, 1000, 2000 dan $5000 \mathrm{mg} / \mathrm{kgbb}$ ) karena diperoleh p > 0,05, dari hasil yang diperoleh dinyatakan bahwa pemberian EEKBMU dosis tunggal tidak berpengaruh pada berat badan mencit. Berat badan diukur secara berkala (Gupta et al., 2012).

Table. 2. Hasil rata-rata berat badan

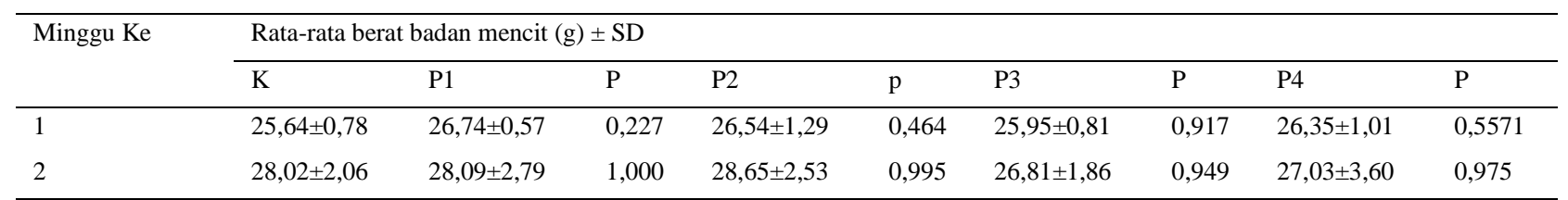

Keterangan: $\mathrm{K}=$ kontrol; $\mathrm{P} 1$ = dosis $500 \mathrm{mg} / \mathrm{kg}$ bb; P2 = dosis $1000 \mathrm{mg} / \mathrm{kg}$ bb; P3 = dosis $2000 \mathrm{mg} / \mathrm{kg}$ bb; P4 = dosis $5000 \mathrm{mg} / \mathrm{kg}$ bb; SD = standar deviasi; $\mathrm{p}=$ angka kebermaknaan

\subsection{Hasil pengamatan Kematian Hewan}

Jumlah kematian hewan selama 14 hari dapat dilihat pada Tabel 3.

Table. 3. Hasil pengamatan kematian mencit

\begin{tabular}{lll}
\hline Kelompok & Jumlah Mencit & Jumlah Kematian \\
\hline Kontrol & 5 ekor & 0 \\
EEKBMU dosis $500 \mathrm{mg} / \mathrm{kg}$ bb & 5 ekor & 0 \\
EEKBMU dosis $1000 \mathrm{mg} / \mathrm{kg} \mathrm{bb}$ & 5 ekor & 0 \\
EEKBMU dosis $2000 \mathrm{mg} / \mathrm{kg} \mathrm{bb}$ & 5 ekor & 0 \\
EEKBMU dosis $5000 \mathrm{mg} / \mathrm{kg} \mathrm{bb}$ & 5 ekor & 0 \\
\hline
\end{tabular}

Berdasarkan Tabel 3 setelah pemberian EEKBMU dosis tunggal diberikan secara oral sampai dengan dosis 5000 $\mathrm{mg} / \mathrm{kg} \mathrm{bb}$, tidak ada satu pun mencit yang mati dari semua kelompok sehingga LD50 tidak dapat ditentukan. Nilai LD50 bukan suatu tetapan biologi mutlak, melainkan hanya merupakan salah satu petunjuk toksisitas akut. Bila toksisitasnya rendah, LD50 tidak perlu ditentukan secara tepat dan suatu angka perkiraan sudah dapat memberi manfaat (Retnomurti, 2008). Pada dosis maksimal tidak ada kematian pada hewan uji, maka jelas senyawa tersebut termasuk dalam kriteria "Praktis Tidak Toksik".

Table. 4. Hasil berat organ relatif

\begin{tabular}{|c|c|c|c|c|c|c|c|c|c|}
\hline \multirow[t]{2}{*}{ Organ } & \multicolumn{9}{|c|}{ Rata-rata berat organ relatif $\pm \mathrm{SD}$} \\
\hline & $\mathrm{K}$ & $\mathrm{P} 1$ & $\mathrm{P}$ & $\mathrm{P} 2$ & $\mathrm{p}$ & P3 & $\mathrm{P}$ & $\mathrm{P} 4$ & $\mathrm{P}$ \\
\hline Hati & $5,09 \pm 1,34$ & $5,67 \pm 0,83$ & 0,922 & $5,24 \pm 0,88$ & 1,000 & $6,23 \pm 0,96$ & 0,518 & $6,41 \pm 1,48$ & 0,376 \\
\hline
\end{tabular}


Table. 5. Hasil pemeriksaan makropatologi organ hati mencit

\begin{tabular}{llll}
\hline Kelompok & Warna & Permukaan & Konsistensi \\
\hline $\mathrm{K}$ & Merah Kecoklatan & Licin & Kenyal \\
P1 & Merah Kecoklatan & Licin & Kenyal \\
P2 & Merah Kecoklatan & Licin & Kenyal \\
P3 & Pucat & Tidak Licin & Tidak Kenyal \\
P4 & Pucat & Tidak Licin & Tidak Kenyal \\
\hline Keterangan: $\mathrm{K}=$ kontrol; $\mathrm{P} 1=$ dosis $500 \mathrm{mg} / \mathrm{kg} \mathrm{bb} ; \mathrm{P} 2=$ dosis $1000 \mathrm{mg} / \mathrm{kg}$ bb; P3 = dosis $2000 \mathrm{mg} / \mathrm{kg}$ bb; P4 = dosis 5000 \\
mg/kg bb.
\end{tabular}

Berdasarkan hasil uji statistik menunjukkan bahwa adanya perubahan warna organ hati pada kelompok dosis 2000 dan $5000 \mathrm{mg} / \mathrm{kg}$ bb. Hati terlibat dalam metabolisme makanan serta sebagian besar obat dan toksikan (Retnomurti, 2008). Zat makanan, obat-obatan serta toksisikan yang masuk melalui saluran pencernaan setelah diserap oleh epitel usus akan dibawa oleh vena vorta ke hati, oleh karena itu hati merupakan organ yang sangat potensial menderita keracunan lebih dahulu sebelum organ lain (Santoso, 2006). Perubahan warna menjadi salah satu parameter terjadinya efek toksik yang bertujuan mendapatkan informasi mengenai toksisitas zat uji yang berkaitan dengan organ sasaran dan efek terhadap organ tersebut (Lu,1994).

\subsection{Hasil Pemeriksaan Histopatologi Organ Hati}

Salah satu parameter uji toksisitas untuk melihat adanya kerusakan pada jaringan hati maka dilakukan pengamatan gambaran histopatologi sel hati mencit yang dapat dilihat pada Gambar 1. A, B, C juga Gambar 2 A dan B.

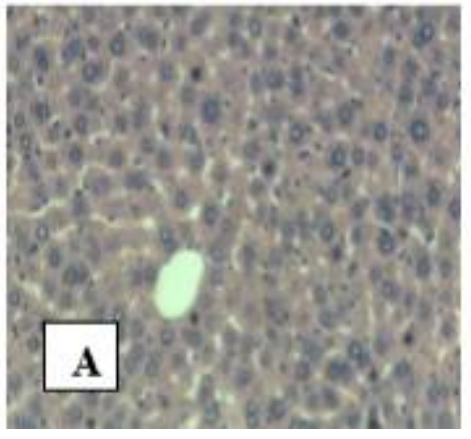

A. Na-CMC $0,5 \% \mathrm{~b} / \mathrm{v}$ organ hati mencit jantan
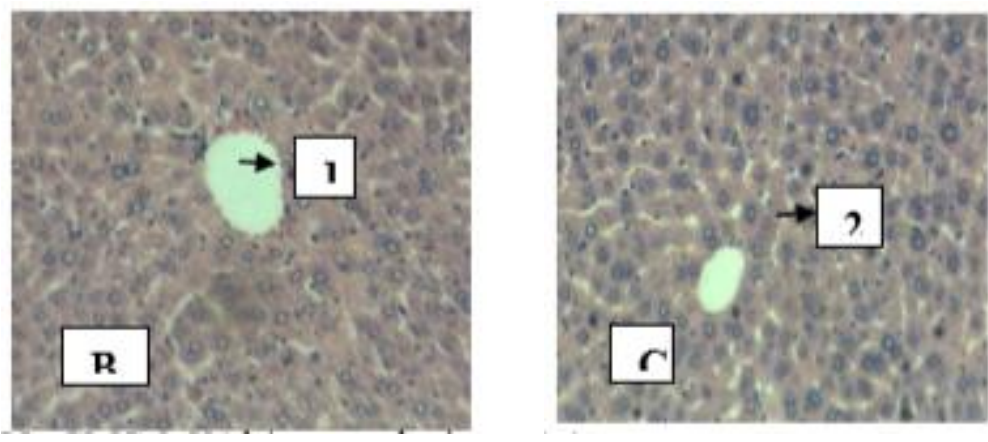

B. EEKBMU dosis $500 \mathrm{mg} / \mathrm{kg}$ bb organ hati mencit jantan

C. EEKBMU dosis $1000 \mathrm{mg} / \mathrm{kg}$ bb organ hati mencit jantan

Fig. 1. Histopatologi 


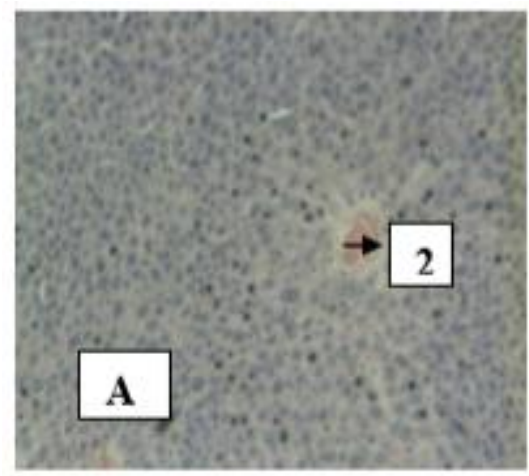

A. EEKBMU dosis $2000 \mathrm{mg} / \mathrm{kg}$ bb organ hati mencit jantan

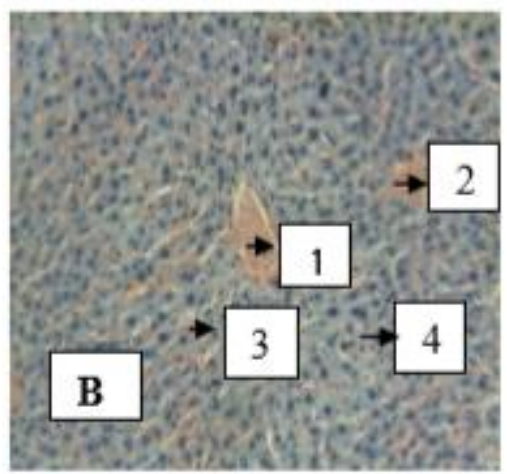

B. EEKBMU dosis $1000 \mathrm{mg} / \mathrm{kg}$ bb organ hati mencit jantan

Fig. 2. Histopatologi

Kerusakan hati dapat dilihat melalui pemeriksaan kadar enzim, makropatologi hati dan gambaran histopatologi sel hati. Sebagaimana dapat dilihat pada pengamatan histopatologi pada mencit kelompok kontrol yang diberi suspensi $\mathrm{Na}-\mathrm{CMC}$ 0,5\% dan EEKBMU dosis $500 \mathrm{mg} / \mathrm{kg}$ bb tidak terdapat kerusakan pada organ, vena sentral masih normal, hepatosit utuh, sinusoid tersusun secara radier kearah vena sentral. Pada dosis $1000 \mathrm{mg} / \mathrm{kg}$ bb terjadi kerusakan berupa sel nekrosis yang ditandai dengan inti sel mengecil dan berwarna kehitaman (kariopiknosis). Hal ini dapat dimaklumi karena uji toksisitas akut adalah suatu pengujian untuk mendeteksi efek toksik yang muncul setelah pemberian sediaan uji yang diberikan secara oral dalam dosis tunggal, atau dosis berulang yang diberikan dalam waktu 24 jam [1].

Pada gambar dosis $2000 \mathrm{mg} / \mathrm{kg}$ bb dapat dilihat terjadi kerusakan pada hati ditandai dengan adanya nekrosis dan terjadinya kongesti pada vena sentral dan sinusoid tidak tersusun secara radier menuju vena sentral. Pada gambar dosis $5000 \mathrm{mg} / \mathrm{kg}$ bb terjadi kongesti pada vena sentral dan sinusoid. Kerusakan pada hati ditandai dengan adanya nekrosis dan terjadinya kongesti pada sinusoid dan vena sentral, Kongesti pada vena sentral diakibatkan oleh lisisnya sel endotel sehingga lingkaran tidak utuh dan akhirnya lingkaran menjadi tidak jelas. Kerusakan pada vena sentral berkaitan dengan perannya pada sirkulasi, dimana vena sentralis menerima darah dari sinusoid-sinusoid yaitu $25 \%$ dialirkan dari arteri hepatika dan $75 \%$ dari vena porta yang mengalirkan darah dari saluran cerna hasil absorbsi usus. Vena sentral banyak menampung nutrient-nutrient dan zat-zat hasil metabolisme yang dapat bersifat toksik maupun nontoksik, banyaknya darah yang ditampung vena sentralis akan menyebabkan konsentrasi zat yang bersifat toksik jauh lebih besar sehingga hal inilah yang memperjelas kerusakan pada vena sentralis [6]. Nekrosis merupakan kematian sel atau jaringan pada organisme hidup. Inti sel yang mati dapat dilihat lebih kecil dan lebih padat (kariopiknosis), Nekrosis merupakan suatu manifestasi toksik yang berbahaya tetapi tidak selalu kritis karena hati mempunyai kapasitas pertumbuhan kembali yang luar biasa [5].

Hati memiliki kemampuan regenerasi yang luar biasa, hilangnya jaringan hati akibat tindakan bedah atau oleh kerja substansi toksik memicu mekanisme yang merangsang sel-sel hati membelah, sampai massa jaringan aslinya pulih kembali. Jaringan hati yang diregenerasi umumnya serupa dengan jaringan yang hilang. Tetapi bila kerusakan itu terjadi berulang-ulang atau terus menerus pada organ ini, maka terbentuk banyak jaringan ikat bersama regenerasi sel hati [3]. Hati merupakan organ yang terlibat dalam metabolisme zat makanan dan sebagian besar obat dan toksikan. Zat makanan yang masuk melalui saluran cerna setelah diserap oleh epitel usus akan dibawa oleh vena porta ke hati. Oleh sebab itu, hati menjadi organ yang sangat potensial menderita keracunan lebih dahulu sebelum organ lain dan terjadi haemorrhagia [10]. 


\section{Kesimpulan dan Saran}

Hasil pemeriksaan histopatologi organ hati mencit menunjukkan bahwa pemberian EEKBMU pada kelompok kontrol, dosis $500 \mathrm{mg} / \mathrm{kg}$ bb dan dosis $1000 \mathrm{mg} / \mathrm{kg}$ bb tidak menyebabkan ketoksikan, sedangkan pada dosis 2000 $\mathrm{mg} / \mathrm{kg}$ bb dan $5000 \mathrm{mg} / \mathrm{kg}$ bb dapat menyebabkan ketoksikan pada organ hati. Pada dosis maksimal tidak ada kematian pada hewan uji, dalam penelitian ini LD50 tidak dapat ditentukan. jelas senyawa tersebut termasuk dalam kriteria "Praktis Tidak Toksik". Disarankan pada penelitian selanjutnya dilakukan penelitian lebih lanjut untuk meneliti potensi toksisitas subkronis dan kronis dari ekstrak etanol kulit buah markisa ungu..

\section{Referensi}

[1] BPOM RI. (2011). Pedoman Uji Toksisitas Nonklinik Secara In Vivo. Jakarta: Pusat Riset Obat dan Makanan BPOM RI. Halaman 25 - 29.

[2] Gupta, D., dan Bhardwaj, S. (2012). Study of Acute, Subacute and Chronic Toxicity Test. International Journal of Advanced Research in Pharmaceutical and Bio Science (IJARPB). 1(2): 103 - 129.

[3] Junqueira, L.C., dan Carneiro, J. (2003). Histologi Dasar. Editor Frans Dany. Edisi X. Jakarta: Buku Kedokteran EGC. Halaman 318 - 320 , $330-331$.

[4] Karsinah, R.C. Hutabarat, dan A. Mansyur. (2010). Markisa Asam. Jurnal Iptek Hortikultura. Balai Penelitian Tanaman Buah Tropika. No. 6- Agustus 240. Halaman 30.

[5] Lu, F.C. (1994). Toksikologi Dasar: Asas, Organ Sasaran, dan Penilaian Resiko. Edisi II. Jakarta: UIP. Halaman 47 - 48, 74, 93 - 97,206 211.

[6] Price, S.A., dan Wilson, L.M. (1997). Patofisiologi Konsep Klinis Proses-proses Penyakit. Jakarta: Penerbit Buku Kedokteran EGC. Hal. $426-433$.

[7] Pudjiastuti., dan Yun, S. A. (2009). Uji Gelagat dan Uji Analgesik Ekstrak Etanol Daun Kembang Sungsang (Gloriosa superba L) Pada hewan Coba. Puslitbag Biomedis dan Farmasi. I(02).

[8] Rasyid, M. (2012). Uji Toksisitas Akut Ekstrak Etanol Lempuyang Wangi (Zingiber aromaticum Val.) Pada Mencit. Majalah Farmasi dan Farmakologi. 16(01): 13-19.

[9] Retnomurti, H.R. (2008). Pengujian Toksisitas Akut Ekstrak Buah Merah (Pandamous conoideum L) Secara In Vivo. Skripsi. Bogor : Fakultas Teknologi Pertanian Institut Pertanian Bogor. Hal. 30-31.

[10] Santoso, H,B., dan Nurliani, A. (2006). Efek Doksisiklin Selama Masa Organogenesis pada Struktur Histologi Organ Hati dan Ginjal Feteus Mencit. Bioscience. 3(1): 15 - 27.

[11] Sherma, Zibadi., Reza, F., Satoru, M., (2007). Antihypertensive Effect Of Purple Passion Fruit Peel Extract in Rats and Humans. Faseb journal. Univercity of Arizona. Journal II: 384.3

[12] WHO. (2013). Traditional Medicine Strategy 2014-2023. China: World Health Organization Press. Halaman 15 - 17.

[13] Widowati, L., Winarno, M.W., Intan, PR (2014) Toksisitas akut dan sub kronis Ramuan Ekstrak Kelor dan Klabet sebagai Pelancar ASI dan Penambah Gizi. Jurnal Kefarmasian Indonesia.Vol.4.2.2014 Hal. 51-64 